\title{
Factors affecting job satisfaction of lecturers - evidence from Vietnamese universities
}

\author{
Ngoc Thi Bui \\ Faculty of Accountancy, \\ University of Labour and Social Affairs, Vietnam
}

\begin{abstract}
The quality of training is an important issue and is of special concern to universities. Lecturers has a pioneering role in innovation of higher education management since the quality of higher education is always associated with the quality of lecturers. Assessing job satisfaction of lecturers is a fundamental step for universities to improve quality and job satisfaction of lecturers as well as attract and retain qualified lecturers. This study aims at assessing job satisfaction of lecturers in Vietnamese universities. For the purpose of this study, quantitative research method was applied. The questionnaires were sent randomly to 131 lecturers from 48 universities in Vietnam via email and google doc. Then, data was analyzed by various tool including descriptive statistics, frequency, exploratory factor analysis and multiple regression analysis. The study examined four factors affecting lecturer job satisfaction include Facilities, Job Characteristics, Salaries and Fringe Benefits, Development Opportunities. Specifically, Job Characteristics have the strongest impact on lecturer job satisfaction while Salary and Fringe Benefits have the smallest impact on lecturer job satisfaction. The research on factors affecting job satisfaction of lecturers helps universities to develop appropriate policies in order to maintain and develop lecturers, as well as attract talents and prevent the "brain drain".
\end{abstract}

Keywords: Education, job satisfaction, lectures, university, opportunity, Vietnam

\section{INTRODUCTION}

Currently, the quality of training is an important issue and is of special concern to universities. Improvement of education quality and human resources is considered as one of the most important duties of universities to meet the standards and confront new challenges (Sharma, 2009). It is proved that innovation of higher education management is a breakthrough in which development of scale must go along with quality assurance of education. Specially, lecturers has a pioneering role in innovation of higher education management since the quality of higher education is always associated with the quality of lecturers (Hughes, 2006).

By 2018, Vietnam had appropximately 700 universities, institutes and colleges, nearly 73,000 lecturers, and more than 16,500 doctors. Vietnamese universities are facing many issues related to management of lecturers. One typical issue is that many lecturers quit their teaching job in universities to work for other organizations, especially lecturers who have studied abroad. Other issues include the brain drain, low work efficiency, low teaching quality. As a result, universities in Vietnam are unable to meet the requirements and demands of society. Assessing job satisfaction of lecturers is a fundamental step for universities to improve quality and job satisfaction of lecturers as well as attract and retain qualified lecturers. In fact, job satisfaction is one of the most significant motivation for lectureres and is the basis for assessing the quality of a university's resources. Therefore, a good understanding and proper assessment of lecturer job satisfaction is critically important for the success of a university.

What is job satisfaction? There are many different definitions of job satisfaction. Specifically, Hoppock (1935) provided that job satisfaction is a combination of psychological, physiological 
and environmental circumstances which make a person feel satisfied with their work. This first definition of job satisfaction has been used and cited in many latter studies. Herzberg (1959) studied employee satisfaction and believed that it is workers' contentedness with their work or their effort to keep working. Hunt et al. (1975) stated that employees are satisfied with their jobs when they felt contented with promotion opportunities, supervison and relationship with colleagues. Smith (2007) pointed out that work plays a central role in many people's lives and job satisfaction is an important component in the overall happiness of employees. Lee (2007) defined job satisfaction as a state in which employees can feel and be contented when performing work with clear objectives and effective directions. He also provided that job satisfaction is influenced by three factors including expected value, working facilities and treatment of organizations. Job satisfaction reflects attitude towards the job of employees in aspects such as salary, promotion opportunities, relationship with colleagues, work efficiency. Indeed, satisfaction can be understood as a state or feeling of one person coming from comparing value received from using a product/service with their own expectations. The level of satisfaction depends on the difference between received value and expectations. If the received value is lower than expected, the user is discontented and vice versa. The concept of satisfaction is unstable and difficult to quantify. Particularly, in the same working condition, the satisfaction level of each individual is different. With each individual, the level of satisfaction may vary in specific moments and depends on other subjective or objective factors. When workers are satisfied with their work, they will work hard and effectively. Struggles, conflicting opinions, and even silence might sometimes imply workers' dissatisfaction. Generally, job satisfaction is presented by contentedness with work, commitment with organizations, feeling proud of the organizations.

Why the assessment of lecturer job satisfaction is necessary? Hughes (2006) provided that due to fierce competition in recruiting employees, in order to improve the quality of teaching staff and attract qualified, dedicated lecturers, universities need to create a higher level of job satisfaction for lecturers compared to other universities. This will ensure a win-win outcome for both lecturers and the university. When feeling satisfied, lecturers will commit more to their universities, devote their time for teaching and scientific research and continuously improve their knowledge to meet new requirements. In other words, the factor actually determining lecturers' commitment and dedication is job satisfaction.

Job satisfaction is one of the most significant motivations for lecturers and is the basis for assessing the quality of a university's resources. In addition, a good understanding and proper assessment of lecturer job satisfaction is critically important for the success of a university. Therefore, this study is conducted with the following objectives:

- Identifying the importance of lecturer job satisfaction in determining the success of a university

- Investigating and measuring factors affecting job satisfaction of lecturers in universities;

- Proposing potential solutions to help universities attract qualified lecturers and improve training quality.

\section{Prior studies on job satisfaction}

\section{LITERATURE REVIEW}

Job satisfaction is one of the most widely discussed issues in organizational behaviors and human resource management. A number of studies have been conducted in developed countries like the US and European countries which are discussed as follows:

Smith (2007) established a Job Descriptive Index which is highly appreciated in both research and practice, the main content includes: (i) The nature of work including job characteristics, opportunities to use personal competence and feelings when performing tasks; (ii) Training 
and promotion opportunities referring to the training and development of individual competencies and opportunities for promotion within an organization; (iii) Leadership in relation to the relationship between employees and the direct leader; leaders' perspective in performing management; (iv) Colleagues regarding feeling towards behaviors, relationships with others at work, collaboration and supporting each other at work; (v) Salary regarding pay equity, pay periods, salary, pay rise policies and other benefits.

De Witte (2005) pointed out that job satisfaction is related to individual perception and assessment, which are influenced by factors such as their needs, values and expectations. Measuring job satisfaction is a challenging work, because perception in satisfaction is different for different people. According to his study, salary and fringe benefits is an important factor affecting job satisfaction

Spector (1997) defined job satisfaction as how people feel about their jobs and different aspects of their job. He explained that it is the extent to which people like or dislike their jobs. He provided factors to evaluate employee satisfaction and their attitude on several aspects such as: (1) Salary, (2) Opportunities for promotion, (3) Working conditions, (4) Supervision, (5) Colleagues, (6) Communication, (7) Rewards, (8) Benefits.

According to Locke (1969), job satisfaction refers to evaluation of employees about what they like or dislike about their jobs. The assessment depends on many factors such as age, education level, job itself, working environment, and development opportunities. Locke investigated factors affecting job satisfaction and loyalty of employees and the results showed that salary and working conditions are the most influential factors, followed by work pressure, while opportunities for promotion has the lowest impact on job satisfaction.

Rounds et al. (1987) stated that employees' satisfaction is related to three psychological states when they work: (i) The core elements of the job are the basic internal motivation including flexibility skills and meaningful jobs, specified tasks, autonomy, feedback; (ii) The psychological state includes emotional intelligence, understanding the meaning of work, being responsible for the job, understanding the actual outcomes of the job; (iii) The outcomes of work include motivation to do the job better and with high satisfaction. The study also established scales to measure factors affecting work such as job security, salary, relationship with colleagues, relationship with leaders and promotion opportunities.

\section{Prior studies on lecturer job satisfaction}

Henry et al. (2013) investigated the relationship and impact of internal and external job satisfaction on the intention to quit their job of lecturers in three universities in Tanzania. Internal job satisfaction is measured by 12 variables including ability utilization, achievement, activities, authority, creativity, independence, moral values, responsibility, security, social services, social status and diversity. External job satisfaction is measured by 6 variables including: advancement, policies, compensation, recognition, supervision - human relations and supervision - technical. The results indicated that internal satisfaction is a determinant affecting the decision to quit teaching job of lecturers.

Mussie (2012) conducted a study to examine job satisfaction of university lecturers' and pointed out 5 factors affecting job satisfaction: salary and fringe benefits, supervisors, relationship with colleagues, working environment and job characteristics. Particularly, working environment has the highest impact. 
Lutfi et al. (2009) conducted a study to identify factors affecting satisfaction of lecturers and students in tourism. The study was conducted on 150 lecturers and 1,734 students of Canakale Onsekiz Mart University with stem and leaf analysis method. The research results showed that there are many factors affecting satisfaction of teachers and students, in which, job opportunities after graduation has the highest impact on satisfaction of students and remuneration is the most influential factor on satisfaction of lecturers.

Sharma et al. (2009) studied the impact of individual factors on university lecturers' job satisfaction and found that lecturers are moderately satisfied with their jobs, male lecturers are more satisfied than female lecturers. In addition, the study provided that lecturers with a master's degree are more satisfied than those with a bachelor's degree but lecturers holding a doctoral degree have the lowest level of satisfaction. The study concluded that salary and working environment are two factors affecting commitment of lecturers with their universities.

Hughes (2006) conducted research measuring job satisfaction of lecturers. Factors examined in the study include: Job characteristics; Salary; Training and promotion; Colleagues; Benefits; Working conditions; Leadership. The results showed that the two factors that have the most influential impact and are statistically significant to the level of general satisfaction are job characteristics, training and promotion opportunities.

Job satisfaction has become a common research topic regarding performance of workers especially in higher education environment. Griffeth (2000) and Spector (1997) suggested that job dissatisfaction may reduce the quality of teaching and lead to negative behaviors such as quitting jobs. The most important factors affecting lecturer job satisfaction are salary and growth opportunities in universities.

Based on literature review, it can be seen that each study examines different perspectives on the factors affecting job satisfaction of lecturers'. Common factors include salary and benefits, working conditions regarding facilities, development opportunities, relationship with colleagues, and job characteristics. In addition, there are several specified factors such as job security, relationship with leaders, training and learning opportunities, communication environment, and organizational supervision. Vietnam is a developing country with slow development, poor financial situation, out-dated facilities, primitive technology. Therefore, facilities and equipment is an important material foundation for the effective teaching process. Furthermore, Vietnam has a small budget for welfares so old people are not provided with social benefits and only government retirees have pensions. Thus, salary is an important factor which may affect job satisfaction of lecturers. Besides, since lecturers' work is intangible, it is difficult to measure and evaluate. As a result, job characteristics are examined in this study. Last but not least, it is important for lecturers to have development opportunities regarding profession, academic and skills. Therefore, the fourth factor examined in this study is development opportunities. In short, 4 factors are selected in this study to investigate factors affecting job satisfaction of lecturers including facilities, job characteristics of lecturers, salary and fringe benefits, development opportunities.

\section{METHODOLOGY}

\section{Measurement scales}

The preliminary scales are established based on the research objectives, combined with reference to measurement scales of previous studies. Specifically, this study selected and inherited measurement scales of authors including Griffeth (2000) and Spector (1997), Henry et al. (2013), Sharma et al (2009), Mussie (2012), Hughes (2006). After analyzing each study, 
four factors are selected to examine factors affecting lecturer job satisfaction: facilities; job characteristics of lecturers, salary and benefits; development opportunities.

\section{Facilities}

This factor is not examined in many studies in the world. However, Vietnam is a poor country so facilities of universities have not met the teaching requirements. Therefore, facilities may greatly affect job satisfaction of lecturers in universities as good facilities allow lecturers to develop their capacity, creativity at work as well as avoiding occupational diseases, ensuring physical and mental health in the long term. Facilities examined by Smith (2007), Spector (1997), Locke (1969) include lecture halls, classrooms, libraries, laboratories, office, teaching and learning equipment; health care and insurance, fire system.

\section{Job requirements}

Teaching and scientific research are main tasks of university lecturers. Therefore, establishing regulations and policies related to teaching and scientific research as a framework for the operation of institutions is critical work of universities. In each country, there may be a common framework of regulations which may be adjusted and applied depending on specific characteristics of each university. The factor was mentioned in studies of Henry et al. (2013), Smith (2007), Spector (1997), Rounds et al. (1987). Within the scope of this study, following main contents are focused: developing training programs, managing and organizing higher education; making a learning plan for the entire course and each academic year, making timetables and teaching schedules, assigning and arranging teachers, arranging classrooms, organizing and marking examinations at the end of subjects and internships, managing student learning and training results, organizing compilation of lectures, curriculum, e-lectures and websites, connecting with companies in the training process.

\section{Salary and fringe benefits}

Salary and fringe benefits is an important factor determining lecturers' commitment to universities. The criteria for measuring and assessing salary and fringe benefits are examined by Smith (2007), De Witte (2005), Spector (1997), Griffeth (2000), Henry et al. (2013), Sharma et al. (2009), Mussie (2012), Hughes (2006) including: policy regime, calculation method of salary, amount of salary received by employees, pay periods, pay rise policy, bonuses and other benefits that workers receive.

\section{Development opportunities}

Development opportunities related to the working environment is a broad concept covering what is relevant and directly affecting the activities and capacity development of each lecturer. Lecturers who are given many development opportunities are more likely to commit to their universities. Therefore, it is an important factor affecting the development, quality and performance of a university. Research of Smith (2007), De Witte (2005), Locke (1969) Rounds et al. (1987), Henry et al. (2013), Mussie (2012), Sharma et al. (2009), Hughes (2006) agreed that lecturers concern about the following issues: opportunities for development (appointment of positions), opportunities for improving qualifications (expertise, skills, scientific research), noble titles of lecturers (Associate Professor, Professor, excellent lecturer), opportunities to participate in research (school level, ministry level, state level). The fact is that development opportunities of lecturers depend on each university in which the principal is the determiner. There are many different perspectives such as university culture is the root of development as each university builds its own culture and character emphasizing practical actions, human investment and development, appreciating individual creativity, listening and selecting. 
Satisfaction: Inherited the scales of Herzberg (1959), Hunt et al. (1975), Smith (2007) and Lee (2007), job satisfaction is measured by the following variables: lecturers' commitment to universities; lecturers' proud of universities.

The factors affecting job satisfaction of lecturers are summarized in the following figure:

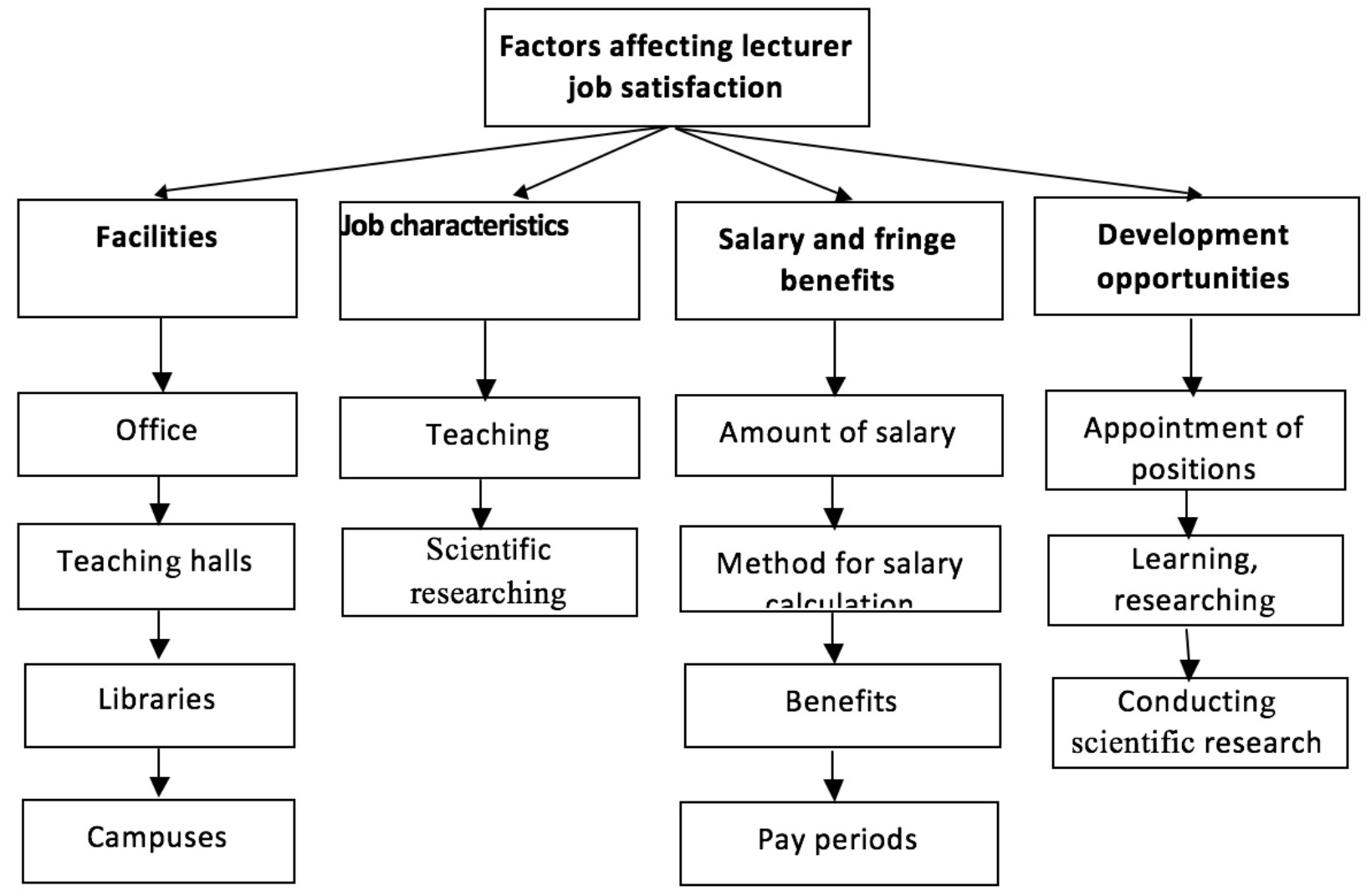

Figure 1. The factors affecting lecturer job satisfaction

\section{Conceptual framework and hypotheses Conceptual framework}

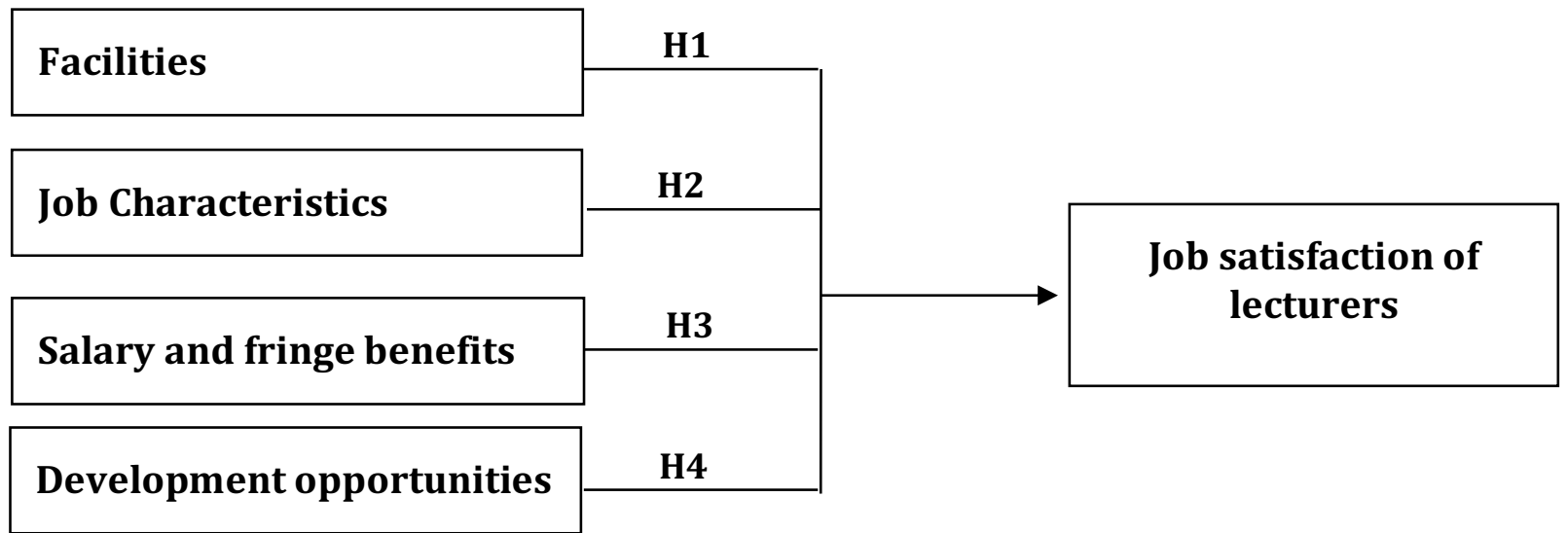

Figure 2.The conceptual framework

\section{Hypotheses}

Based on the literature review and conceptual framework, the research hypotheses are proposed as follows:

Hypothesis H1 - There is a positive relationship between facilities and lecturer job satisfaction 
Hypothesis H2 - There is a positive relationship between job characteristics and lecturer job satisfaction

Hypothesis H3 - There is a positive relationship between salary and fringe benefits and lecturer job satisfaction

Hypothesis H4 - There is a positive relationship between development opportunities and lecturer job satisfaction

\section{Regression equation}

Based on the above hypotheses and variables, the regression equation reflecting the correlation between lecturer job satisfaction and influential is presented as follows:

$$
\text { HAILONGi }=\alpha+\beta 1 F A C i+\beta 2 J O B i+\beta 3 S A L i+\beta 4 O P P i+\varepsilon
$$

In which:

$\alpha$ : Aconstant

$\beta \mathrm{i}$ : Coefficient of each variable

$\varepsilon \mathrm{i}:$ Residual error

Independent variables: Facilities (FAC); Job characteristics of lecturers (JOB); Salary and fringe benefits (SAL); Development opportunities (OPP).

Dependent variable: Job satisfaction of lecturer i (HAILONGi:)

\section{Methodology}

This is a descriptive study, applying quantitative method to investigate factors affecting lecturer job satisfaction. In addition, questionnaires are designed and used to collect data for further analysis. The research process consists of the following steps:

Step 1: Establishing measurement scales: The preliminary scales were established based on the research objectives, combined with reference to measurement scales of previous studies. After analyzing each study, four factors were selected to examine factors affecting lecturer job satisfaction: facilities; job characteristics of lecturers, salary and fringe benefits; development opportunities.

Step 2: Preliminary research: The in-depth interviews were conducted based on the initial preliminary scales. Specifically, pilot testing was conducted with 15 participants to check the contents of questionnaires and adjust measurement scales based on the initial preliminary scales which may substantially improve the research design and research results.

Step 3: Designing a complete questionnaire: In this step, official measurement scales were adjusted based on preliminary research results. These adjustments include correcting the wording, adjusting contents, scales and questionnaire format. In the questionnaire, variables are measured using a 5 -point Likert scale in which $1=$ Strongly disagree; $5=$ Strongly agree.

Step 4: Data collection: In this study, data was collected by sending questionnaires to universities via google.doc. After receiving the answers and eliminating invalid answers, data was gathered and processed by SPSS 22 .

Step 5: Data analysis: Cronbach's Alpha coefficient and Exploratory Factor Analysis (EFA) were used to check internal consistency and reliablity of scales; then, conceptual framework was established to examine factors affecting lecturer job satisfaction. The research model can be written as the following function: Satisfaction $(\mathrm{Y})=\mathrm{f}(\mathrm{X} 1, \mathrm{X} 2, \mathrm{X} 3, \mathrm{X} 4)$, in which $\mathrm{X} 1, \mathrm{X} 2 \ldots$ are influential factors. Research techniques used in this study include descriptive statistics, frequency, multiple regression analysis. 


\section{Quantitative research}

The research was conducted through a survey of lecturers in Vietnamese universities and institutes. Non-probability sampling technique was selected for this study. Specifically, convenience sampling was used because of its speed, cost-effectiveness, and ease of availability of the sample. The total number of questionnaires distributed is 308 in which 75 answers received via internet, 148 answers received from answer sheet papers. However, 27 answers were invalid due to failure to answer all compulsory questions, 6 answers were blank, 59 answers were randomly filled, therefore, only 131 answers were sufficient and appropriate for further analysis of the study. Information of participants is shown in the following table:

Table 1: Respondents' characteristics

\begin{tabular}{|c|c|c|c|c|}
\hline \multicolumn{2}{|c|}{ Đặc điểm } & Frequency & Percent & Cumulative Percent \\
\hline \multirow[t]{3}{*}{ Gender } & Male & 42 & 32,1 & 32,1 \\
\hline & Female & 89 & 67,9 & 100,0 \\
\hline & Total & 131 & 100,0 & \\
\hline \multirow[t]{4}{*}{ Hightest level } & Bachelor & 1 & 0,8 & 0,8 \\
\hline & Master & 100 & 84,0 & 84,9 \\
\hline & Doctor & 18 & 15,1 & 100,0 \\
\hline & Total & 119 & 100,0 & \\
\hline \multirow[t]{6}{*}{ Working time (years) } & $<5$ & 12 & 10,3 & 10,3 \\
\hline & $5-10$ & 71 & 61,2 & 71,6 \\
\hline & $11-15$ & 26 & 22,4 & 94,0 \\
\hline & $16-20$ & 4 & 3,4 & 97,4 \\
\hline & $>20$ & 3 & 2,6 & 100,0 \\
\hline & Total & 116 & 100,0 & \\
\hline \multirow[t]{4}{*}{ Scientific title } & Professor & 4 & 3,1 & 3,1 \\
\hline & Associate Professor & 37 & 28,2 & 31.3 \\
\hline & None & 90 & 68,7 & 100,0 \\
\hline & Total & 131 & 100,0 & \\
\hline
\end{tabular}

(Source: summary of data processed by SPSS 22)

In term of gender, 42 male respondents and 89 female respondents participated in the study accounting for $32.1 \%$ and $67.9 \%$ respectively. Although, it shows a gender imbalance, it is consistent with actual situation of Vietnamese universities. Regarding qualifications, most respondents have a master degree (84\%) while participants having a doctoral degree accounts for $15.1 \%$ and bachelor's degree accounts for only $0.8 \%$. Furthermore, the number of young lecturers in universities accounts for a high proportion (61.2\%) with 5-10 years of working, 26 participants has been working from 11-15 years (accounting for 22.4\%), followed by number of participants working less than 5 years (accounting for 10.3\%), participants working over 20 years account for $2.6 \%$. Generally, lecturers having longer working years require more benefits than young lecturers with less working years. Therefore, in the same condition, the satisfaction level of lecturers working from 16 to over 20 years will be lower than that of the other groups. Regarding academic title of lecturers, professors account for $3.1 \%$, associate professors account for $28.2 \%$, and participants with no title account for $68.7 \%$. The figures are in accordance with the actual structure of Vietnamese universities. 
Table 2. Characteristics of universities participating in the survey

\begin{tabular}{|c|c|c|c|c|}
\hline \multicolumn{2}{|c|}{ Classification of universities } & Frequency & Percent & Cumulative Percent \\
\hline \multirow{6}{*}{ Program } & Economics & 66 & 50,4 & 35,1 \\
\hline & Engineering & 6 & 4,6 & 39,7 \\
\hline & Business administration & 16 & 12,2 & 67,2 \\
\hline & Languages & 25 & 19,1 & 86,3 \\
\hline & Medicine and pharmacy & 18 & 13,7 & 100,0 \\
\hline & Total & 131 & 100,0 & \\
\hline \multirow[t]{4}{*}{ Geographical area } & The North of Vietnam & 108 & 82,4 & 82,4 \\
\hline & The Center of Vietnam & 8 & 6,1 & 88,5 \\
\hline & The South of Vietnam & 15 & 11,5 & 100,0 \\
\hline & Total & 131 & 100,0 & \\
\hline \multirow{5}{*}{$\begin{array}{l}\text { Training scale } \\
\text { (number of } \\
\text { students/year) }\end{array}$} & Less than 5.000 & 35 & 26,7 & 26,7 \\
\hline & From $5.000-10.000$ & 47 & 35,9 & 62,6 \\
\hline & From $10.000-15.000$ & 35 & 26,7 & 89,3 \\
\hline & Over 15.000 & 14 & 10,7 & 100,0 \\
\hline & Total & 131 & 100,0 & \\
\hline \multirow[t]{4}{*}{ Ownership structure } & Public university & 58 & 44,3 & 44,3 \\
\hline & Private university & 36 & 27,5 & 71,8 \\
\hline & $\begin{array}{l}\text { Financially independent } \\
\text { public university }\end{array}$ & 37 & 28,2 & 100,0 \\
\hline & Total & 131 & 100,0 & \\
\hline
\end{tabular}

(Source: summary of data processed by SPSS 22)

For the purpose of this study, questionnaires were sent to 308 lecturers of 48 universities in which 131 valid answers were received from 34 universities. The survey results show that the participating universities have some common characteristics as follows: Firstly, the economic universities account for a large proportion of 50.4\% (66 out of 131companies) which are distributed mainly in The North of Vietnam (accounting for 82.4\%), specially, in Hanoi and nearby provinces such as Hai Duong, Hai Phong, Bac Ninh, Phuc Yen. Secondly, the training scale depends on facilities and equipment, the average area over the number of lecturers, the number of lecturers with academic titles, academic degrees. Particularly, scale of less than 5,000 students/year accounts for $26.7 \%$, scale from 5,000-10,000 students/year accounts for $47 \%$, and the scale of over 15,000 students/year accounts for only $10.7 \%$. In terms of ownership, Vietnamese universities are now mainly public schools, accounting for 44.3\%, financially independent public universities account for $28.2 \%$ and private universities account for $27.5 \%$. By 2023, public universities will become fully financially independent. 


\section{RESEARCH RESULTS}

\section{Descriptive statistics}

Table 3: List of measurement scales

\begin{tabular}{|c|c|c|c|c|}
\hline Factors & Variables & Code & Mean & Sources \\
\hline \multirow{8}{*}{$\begin{array}{l}\text { Facilities }(\mathrm{FAC}) \\
\text { Mean }=2,61\end{array}$} & The number, quality of office & F11 & 2,89 & \multirow{8}{*}{$\begin{array}{l}\text { Smith (2007), } \\
\text { Spector (1997), } \\
\text { Locke (1969) }\end{array}$} \\
\hline & The number, quality of classrooms & F12 & 2,36 & \\
\hline & The number, quality of laboratories & F13 & 2,72 & \\
\hline & $\begin{array}{l}\text { The number, quality of libraries (sources of documents, e- } \\
\text { library, reading rooms) }\end{array}$ & F14 & 2,45 & \\
\hline & The number, quality of canteens & F15 & 2,73 & \\
\hline & The number, quality of teaching/working equipment, & F16 & 2,44 & \\
\hline & The number, quality of parking lots & F17 & 2,60 & \\
\hline & The number, quality of campuses & F18 & 2,68 & \\
\hline \multirow{6}{*}{$\begin{array}{l}\text { Job } \\
\text { characteristics } \\
(\text { JOB) } \\
\text { Mean }=2,98\end{array}$} & $\begin{array}{l}\text { Requirements of teaching (classrooms, studying rooms, time, } \\
\text { number of teaching periods, lecture contents) }\end{array}$ & F21 & 3,02 & \multirow{6}{*}{$\begin{array}{l}\text { Henry et al. (2013), } \\
\text { Smith (2007), } \\
\text { Spector (1997), } \\
\text { Rounds et al. (1987) }\end{array}$} \\
\hline & Requirements of training programs & F22 & 3,19 & \\
\hline & $\begin{array}{l}\text { Requirements of scientific research (research topics, articles, } \\
\text { seminars, standards, number of works, members) }\end{array}$ & F23 & 3,06 & \\
\hline & Requirements of course books, lectures, assignments & F24 & 2,98 & \\
\hline & Requirements of records, science profile & F25 & 2,76 & \\
\hline & Procedures related to teaching & F26 & 2,89 & \\
\hline \multirow{7}{*}{$\begin{array}{l}\text { Salary and fringe } \\
\text { benefits (SAL) } \\
\text { Mean }=2,31\end{array}$} & Salary (amount, calculation method, payment) & F31 & 2,31 & \multirow{7}{*}{$\begin{array}{l}\text { Smith (2007), De } \\
\text { Witte (2005), Spector } \\
\text { (1997), Griffeth } \\
(2000), \text { Henry et al. } \\
(2013), \text { Sharma et al. } \\
(2009), \text { Mussie } \\
(2012), \text { Hughes } \\
(2006)\end{array}$} \\
\hline & Bonus (amount, calculation method, payment) & F32 & 2,14 & \\
\hline & Overtime pay (amount, calculation method, payment) & F33 & 2,21 & \\
\hline & $\begin{array}{l}\text { Allowance for scientific research (amount, calculation } \\
\text { method, payment) }\end{array}$ & F34 & 2,51 & \\
\hline & $\begin{array}{l}\text { Allowance for business trip (amount, calculation method, } \\
\text { payment) }\end{array}$ & F35 & 2,43 & \\
\hline & $\begin{array}{l}\text { Allowance for supervising and marking exams (amount, } \\
\text { calculation method, payment) }\end{array}$ & F36 & 2,24 & \\
\hline & Other benefits (amount, calculation method, payment) & F37 & 2,33 & \\
\hline \multirow{4}{*}{$\begin{array}{l}\text { Development } \\
\text { opportunities } \\
\text { (OPP) } \\
\text { Mean }=2,94\end{array}$} & Opportunities to achieve the title of "Emulation soldier" & F41 & 2,56 & \multirow{4}{*}{$\begin{array}{l}\text { Smith (2007), De } \\
\text { Witte (2005), Locke } \\
\text { (1969) Rounds et al. } \\
\text { (1987), Henry et al. } \\
\text { (2013), Mussie } \\
\text { (2012), Sharma et al. } \\
(2009), \text { Hughes } \\
(2006)\end{array}$} \\
\hline & $\begin{array}{l}\text { Promotion opportunities (appointment of positions, } \\
\text { transferring of positions) }\end{array}$ & F42 & 2,46 & \\
\hline & $\begin{array}{l}\text { Opportunities to improve qualifications (getting a master } \\
\text { degree, internships) }\end{array}$ & F43 & 3,24 & \\
\hline & $\begin{array}{l}\text { Opportunities to participate in training courses (foreign } \\
\text { languages, information technology, vocational program, } \\
\text { scientific research skills, international writing) }\end{array}$ & F44 & 3,46 & \\
\hline \multirow[b]{2}{*}{$\begin{array}{l}\text { Job satisfaction } \\
\text { (HAILONG) }\end{array}$} & Commitment to universities & FA1 & 2,91 & \multirow{2}{*}{$\begin{array}{l}\text { Herzberg (1959), } \\
\text { Hunt et al. (1975), } \\
\text { Smith (2007) và Lee } \\
(2007)\end{array}$} \\
\hline & Proud of universities & FA2 & 2,82 & \\
\hline
\end{tabular}

(Source: summary of data processed by SPSS 22)

\section{Reliability test (Cronbach's Alpha)}

The results of assessing reliability of the scales using Cronbach's alpha coefficient and total correlation coefficient are presented in Table 4 as follows: 
Table 4. Item-Total Statistics of facilities

Cronbach's Alpha = .910; $\mathrm{N}$ of Items: 8

\begin{tabular}{|l|c|c|c|c|c|}
\hline \multicolumn{1}{|c|}{ Variables } & Code & $\begin{array}{c}\text { Scale Mean if } \\
\text { Item Deleted }\end{array}$ & $\begin{array}{c}\text { Scale Variance } \\
\text { if Item } \\
\text { Deleted }\end{array}$ & $\begin{array}{c}\text { Corrected } \\
\text { Item-Total } \\
\text { Correlation }\end{array}$ & $\begin{array}{c}\text { Cronbach's } \\
\text { Alpha if Item } \\
\text { Deleted }\end{array}$ \\
\hline The number, quality of office & F11 & 49,76 & 109,138 &, 618 &, 905 \\
\hline The number, quality of classrooms & F12 & 49,94 & 107,244 &, 659 &, 904 \\
\hline The number, quality of laboratories & F13 & 49,89 & 109,051 &, 557 &, 906 \\
\hline $\begin{array}{l}\text { The number, quality of libraries (sources of } \\
\text { documents, e-library, reading rooms) }\end{array}$ & F14 & 49,66 & 112,988 &, 554 &, 907 \\
\hline The number, quality of canteens & F15 & 49,82 & 111,208 &, 534 &, 907 \\
\hline The number, quality of teaching/working equipment, & F16 & 50,03 & 109,796 &, 582 &, 906 \\
\hline The number, quality of parking lots & F17 & 49,83 & 111,167 &, 513 &, 907 \\
\hline The number, quality of campuses & F18 & 49,81 & 108,529 &, 504 &, 908 \\
\hline
\end{tabular}

Facilities consist of 8 observed variables. It is shown from the table that overall items have $\alpha=$ $0.910>0.6$. In addition, Corrected Item-Total Correlation coefficients are satisfactory with values of over 0.4 . Therefore, the reliability of facilities' measure is appropriate and 8 observed variables are used for further analysis

Table 5. Item-Total Statistics of job characteristics of lecturers Cronbach's Alpha = .897; $\mathrm{N}$ of Items: 6

\begin{tabular}{|c|c|c|c|c|c|}
\hline Variables & Code & $\begin{array}{l}\text { Scale Mean if } \\
\text { Item Deleted }\end{array}$ & \begin{tabular}{|c|} 
Scale Variance \\
if Item \\
Deleted
\end{tabular} & $\begin{array}{l}\text { Corrected } \\
\text { Item-Total } \\
\text { Correlation }\end{array}$ & $\begin{array}{l}\text { Cronbach's } \\
\text { Alpha if Item } \\
\text { Deleted } \\
\end{array}$ \\
\hline $\begin{array}{l}\text { Requirements of teaching (classrooms, studying } \\
\text { rooms, time, number of teaching periods, contents) }\end{array}$ & $\mathrm{F} 21$ & 46,36 & 94,364 & ,612 & ,890 \\
\hline Requirements of training programs & $\mathrm{F} 22$ & 46,55 & 90,443 &, 629 & ,888 \\
\hline $\begin{array}{l}\text { Requirements of scientific research (research topic, } \\
\text { article, seminar, standard, number of works, } \\
\text { members) }\end{array}$ & F23 & 46,58 & 93,877 & 609 & ,889 \\
\hline Requirements of course books, lectures, homework & F24 & 46,55 & 90,693 &, 676 & ,887 \\
\hline Requirements of records, science profile & F25 & 46,64 & 92,176 & ,598 & ,890 \\
\hline Procedures related to teaching & F26 & 46,79 & 90,422 & ,668 & ,887 \\
\hline
\end{tabular}

Job characteristics of lecturers consist of 6 observed variables. It is shown from the table that overall items have $\alpha=0.897>0.6$. In addition, Corrected Item-Total Correlation coefficients are satisfactory with values of over 0.4 . Therefore, the reliability of job characteristics' measure is appropriate and 6 observed variables are used for further analysis.

Table 6. Item-Total Statistics of salary and fringe benefits Cronbach's Alpha = .899; $\mathrm{N}$ of Items: 7

\begin{tabular}{|l|c|c|c|c|c|}
\hline \multicolumn{1}{|c|}{ Variables } & Code & $\begin{array}{c}\text { Scale Mean if } \\
\text { Item Deleted }\end{array}$ & $\begin{array}{c}\text { Scale Variance } \\
\text { if Item } \\
\text { Deleted }\end{array}$ & $\begin{array}{c}\text { Corrected } \\
\text { Item-Total } \\
\text { Correlation }\end{array}$ & $\begin{array}{c}\text { Cronbach's } \\
\text { Alpha if Item } \\
\text { Deleted }\end{array}$ \\
\hline Salary (amount, calculation method, payment) & F31 & 21,09 & 36,842 &, 656 &, 889 \\
\hline $\begin{array}{l}\text { Bonus (amount, calculation method, payment) } \\
\text { Overtime pay (amount, calculation method, } \\
\text { payment) }\end{array}$ & F32 & 20,81 & 39,350 &, 515 &, 897 \\
\hline $\begin{array}{l}\text { Allowance for scientific research (amount, } \\
\text { calculation method, payment) }\end{array}$ & F34 & 21,37 & 37,825 &, 763 &, 883 \\
\hline $\begin{array}{l}\text { Allowance for business trip (amount, calculation } \\
\text { method, payment) }\end{array}$ & F35 & 21,44 & 39,098 &, 619 &, 894 \\
\hline $\begin{array}{l}\text { Allowance for supervising and marking exams } \\
\text { (amount, calculation method, payment) }\end{array}$ & F36 & 21,20 & 36,714 &, 672 &, 888 \\
\hline $\begin{array}{l}\text { Other benefits (amount, calculation method, } \\
\text { payment) }\end{array}$ & F37 & 21,11 & 37,563 &, 658 &, 889 \\
\hline
\end{tabular}


Salary and fringe benefits consist of 7 observed variables. It is shown from the table that overall items have $\alpha=0.899>0.6$. In addition, Corrected Item-Total Correlation coefficients are satisfactory with values of over 0.4 . Therefore, the reliability of salary and fringe benefits' measure is appropriate and 7 observed variables are used for further analysis.

Table 7. Item-Total Statistics of opportunities to develop Cronbach's Alpha = .826; $\mathrm{N}$ of Items: 4

\begin{tabular}{|l|c|c|c|c|c|}
\hline \multicolumn{1}{|c|}{ Variables } & Code & $\begin{array}{c}\text { Scale Mean if } \\
\text { Item Deleted }\end{array}$ & $\begin{array}{c}\text { Scale } \\
\text { Variance if } \\
\text { Item Deleted }\end{array}$ & $\begin{array}{c}\text { Corrected } \\
\text { Item-Total } \\
\text { Correlation }\end{array}$ & $\begin{array}{c}\text { Cronbach's } \\
\text { Alpha if Item } \\
\text { Deleted }\end{array}$ \\
\hline $\begin{array}{l}\text { Opportunities to achieve the title of “Emulation soldier" } \\
\begin{array}{l}\text { Promotion opportunities (appointment of positions, } \\
\text { transferring) }\end{array}\end{array}$ & $\mathrm{F} 41$ & 15,54 & 12,606 &, 500 &, 820 \\
\hline $\begin{array}{l}\text { Opportunities to improve qualifications (getting a } \\
\text { master degree, internships) }\end{array}$ & $\mathrm{F} 43$ & 15,59 & 11,776 &, 641 &, 788 \\
\hline $\begin{array}{l}\text { Opportunities to participate in training courses foreign } \\
\text { languages, information technology, vocational program, } \\
\text { scientific research skills, international writing) }\end{array}$ & $\mathrm{F} 44$ & 15,71 & 12,836 &, 555 &, 806 \\
\hline
\end{tabular}

Development opportunities consist of 4 observed variables. It is shown from the table that overall items have $\alpha=0.826>0.6$. In addition, Corrected Item-Total Correlation coefficients are satisfactory with values of over 0.4 . Therefore, the reliability of development opportunities' measure is appropriate and 4 observed variables are used for further analysis.

Table 8. Item-Total Statistics of job satisfaction Cronbach's Alpha = .908; $\mathrm{N}$ of Items: 2

\begin{tabular}{|l|c|c|c|c|c|}
\hline \multicolumn{1}{|c|}{ Variables } & Code & $\begin{array}{c}\text { Scale Mean if } \\
\text { Item Deleted }\end{array}$ & $\begin{array}{c}\text { Scale Variance } \\
\text { if Item } \\
\text { Deleted }\end{array}$ & $\begin{array}{c}\text { Corrected } \\
\text { Item-Total } \\
\text { Correlation }\end{array}$ & $\begin{array}{c}\text { Cronbach's } \\
\text { Alpha if Item } \\
\text { Deleted }\end{array}$ \\
\hline Commitment to universities & FA1 & 49,71 & 108,650 &, 617 &, 905 \\
\hline Proud of universities & FA2 & 49,53 & 109,455 &, 565 &, 906 \\
\hline
\end{tabular}

Job satisfaction consists of 2 observed variables. It is shown from the table that overall items have $\alpha=0.908>0.6$. In addition, Corrected Item-Total Correlation coefficients are satisfactory with values of over 0.4 . Therefore, the reliability of job satisfaction's measure is appropriate and 2 observed variables are used for further analysis.

\section{Exploratory Factor Analysis}

Exploratory factor analysis (EFA) is a statistical technique that is used to reduce data to a smaller set of summary variables and to explore the underlying theoretical structure of the phenomena. Explore Factor Analysis must satisfy the following requirements: Factor loading> 0.5 and $\mathrm{KMO} \leq 0.5 \leq 1$ and Bartlett test the statistical significance (Sig. $<0.05$ ) and Percentage of variance in Extraction Sums of Squared Loadings > 50\% indicating percentage variation of the observed variables. Furthermore, correlations of at least 0.30 are required between the research variables. EFA is conducted and results are explained as follows:

The first Exploratory Factor Analysis: "the number, quality of parking lots" (F17) is eliminated as value of factor loading is -0.539

The second Exploratory Factor Analysis: "Allowance for supervising, marking exams" (F36) is eliminated as value of factor loading is -0.566

The third Exploratory Factor Analysis: All items have factor loading $>0.5$ and the results are shown in the following table 
Table 9: KMO and Bartlett's test

\begin{tabular}{|l|l|l|}
\hline Kaiser-Meyer-Olkin Measure of Sampling Adequacy. & 809 \\
\hline Bartlett's Test of Sphericity & Approx. Chi-Square & 2193,157 \\
\cline { 2 - 3 } & Df & 406 \\
\cline { 2 - 3 } & Sig. & 000 \\
\hline
\end{tabular}

The table shows that value of KMO $=0.809$ which means the sample is adequate and factor analysis can be proceeded. In addition, the value of significance was 0.000 which is lower than 0.001. This means factor analysis is valid and there may be statistically significant interrelationship between variables. Therefore, it can be concluded that factor analysis is an appropriate technique for further analysis.

Table 10.Total Variance Explained

\begin{tabular}{|c|c|c|c|c|c|c|c|c|c|}
\hline \multirow{2}{*}{ Component } & \multicolumn{3}{|c|}{ Initial Eigenvalues } & \multicolumn{3}{|c|}{$\begin{array}{c}\text { Extraction Sums of Squared } \\
\text { Loadings } \\
\end{array}$} & \multicolumn{3}{|c|}{$\begin{array}{c}\text { Rotation Sums of Squared } \\
\text { Loadings } \\
\end{array}$} \\
\hline & Tổng & Tỷ lệ\% & $\begin{array}{l}\text { Phần trăm } \\
\text { tích lũy }\end{array}$ & Tổng & Tỷ lệ\% & \begin{tabular}{|c} 
Phần trăm \\
tích lũy
\end{tabular} & Tổng & Tỷ lệ\% & \begin{tabular}{|c|} 
Phần trăm \\
tích lũy
\end{tabular} \\
\hline 1 & 9,809 & 33,823 & 33,823 & 9,809 & 33,823 & 33,823 & 5,322 & 18,352 & 18,352 \\
\hline 2 & 3,165 & 10,914 & 44,737 & 3,165 & 10,914 & 44,737 & 4,557 & 15,714 & 34,066 \\
\hline 3 & 2,546 & 8,780 & 53,517 & 2,546 & 8,780 & 53,517 & 4,033 & 13,907 & 47,974 \\
\hline 4 & 2,003 & 6,907 & 60,424 & 2,003 & 6,907 & 60,424 & 3,611 & 12,450 & 60,424 \\
\hline 5 & 1,259 & 4,343 & 64,767 & & & & & & \\
\hline 6 & 1,155 & 3,981 & 68,748 & & & & & & \\
\hline 7 & 1,035 & 3,570 & 72,318 & & & & & & \\
\hline 8 & ,896 & 3,089 & 75,407 & & & & & & \\
\hline 9 & 853 & 2,901 & 78,308 & & & & & & \\
\hline 10 & 801 & 2,893 & 81,201 & & & & & & \\
\hline 11 & 691 & 2,783 & 83,984 & & & & & & \\
\hline 12 & 632 & 2,679 & 86,663 & & & & & & \\
\hline 13 & 492 & 2,506 & 89,169 & & & & & & \\
\hline 14 & ,449 & 2,403 & 91,572 & & & & & & \\
\hline 15 & 429 & 2,160 & 93,732 & & & & & & \\
\hline 16 & 367 & 1,892 & 95,624 & & & & & & \\
\hline 17 & 351 & 1,635 & 97,259 & & & & & & \\
\hline 18 & ,320 & 1,496 & 98,755 & & & & & & \\
\hline 19 & ,249 & 1,141 & 99,896 & & & & & & \\
\hline 20 & ,227 & ,975 & 99,897 & & & & & & \\
\hline 21 & 156 & 856 & 99,898 & & & & & & \\
\hline 22 & 125 & 795 & 99,899 & & & & & & \\
\hline 23 & 119 & 698 & 99,899 & & & & & & \\
\hline 24 & 096 & ,521 & 99,999 & & & & & & \\
\hline 25 & , 080 & ,425 & 100,000 & & & & & & \\
\hline
\end{tabular}

\section{Extraction Method: Principal Component Analysis.}

The table of total variance explained shows that the values of Initial Eigenvalues ranging from 2.003 to 9.809 are satisfactory; The percentage of extracted variance is $60.424 \%$. Therefore, 4 extracted factors explained $60.424 \%$ of the variability of the underlying factors. In addition, the KMO and Bartlett's test results are consistent with testing standards. 
Table 11.Rotated Component Matrixa

\begin{tabular}{|c|c|c|c|c|c|}
\hline \multirow{2}{*}{ Observed variable } & \multirow{2}{*}{ Code } & \multicolumn{4}{|c|}{ Component } \\
\hline & & 1 & 2 & 3 & 4 \\
\hline The number, quality of office & F11 & ,794 & & & \\
\hline The number, quality of classrooms & F12 & ,781 & & & \\
\hline The number, quality of laboratories & F13 & ,770 & & & \\
\hline $\begin{array}{l}\text { The number, quality of libraries (sources of documents, e- } \\
\text { library, reading rooms) }\end{array}$ & F14 & ,723 & & & \\
\hline The number, quality of canteens & F15 & ,715 & & & \\
\hline The number, quality of teaching/working equipment, & F16 & 678 & & & \\
\hline The number, quality of parking lots & F18 & 609 & & & \\
\hline The number, quality of campuses & F21 & & 849 & & \\
\hline $\begin{array}{l}\text { Requirements of teaching (classrooms, studying rooms, } \\
\text { time, number of teaching periods, lecture contents) }\end{array}$ & F22 & & ,799 & & \\
\hline Requirements of training programs & F23 & & ,732 & & \\
\hline $\begin{array}{l}\text { Requirements of scientific research (research topics, } \\
\text { articles, seminars, standards, number of works, members) }\end{array}$ & F24 & & ,721 & & \\
\hline Requirements of course books, lectures, assignments & F25 & & ,672 & & \\
\hline Requirements of records, science profile & F26 & &, 559 & & \\
\hline Procedures related to teaching & F31 & & & 801 & \\
\hline Salary (amount, calculation method, payment) & F32 & & & ,773 & \\
\hline Bonus (amount, calculation method, payment) & F33 & & & 632 & \\
\hline Overtime pay (amount, calculation method, payment) & F34 & & & 627 & \\
\hline $\begin{array}{l}\text { Allowance for scientific research (amount, calculation } \\
\text { method, payment) }\end{array}$ & F35 & & & ,615 & \\
\hline $\begin{array}{l}\text { Allowance for business trip (amount, calculation method, } \\
\text { payment) }\end{array}$ & F37 & & &, 546 & \\
\hline $\begin{array}{l}\text { Allowance for supervising and marking exams (amount, } \\
\text { calculation method, payment) }\end{array}$ & F41 & & & & ,823 \\
\hline Other benefits (amount, calculation method, payment) & F42 & & & & ,821 \\
\hline Opportunities to achieve the title of "Emulation soldier" & F43 & & & & 811 \\
\hline $\begin{array}{l}\text { Promotion opportunities (appointment of positions, } \\
\text { transferring of positions) }\end{array}$ & F44 & & & & ,784 \\
\hline
\end{tabular}

The table shows output of the rotated component matrix representing loadings of variables onto each factor and items loading on each component measure a specific variable with loading factors greater than 0.5 . Thus, 23 variables classified as 4 groups are acceptable. In which, "the number, quality of campuses" (F21) has the largest impact on job satisfaction (0.849), "allowance for business trip" (F37) has the least impact (0.546). However, a multivariate regression analysis should be conducted to identify impact of each factor on job satisfaction. The observed variables constituting each factor and their impact are shown as follows:

Factor 1 (X1): Facilities: include 7 observed variables, the impact of each item on factor 1 is shown as the following equation:

$\mathrm{X} 1=0.794 * \mathrm{~F} 11+0.781 * \mathrm{~F} 12+0.770 * \mathrm{~F} 13+0.723 * \mathrm{~F} 14+0.715 * \mathrm{~F} 15+0.678 * \mathrm{~F} 16+0.609 * \mathrm{~F} 18$

Factor 2 (X2): Job characteristics: include 6 observed variables, the impact of each item on factor 2 is shown as the following equation:

$\mathrm{X} 2=0.849 * \mathrm{~F} 21+0.799 * \mathrm{~F} 22+0.732 * \mathrm{~F} 23+0.721 * \mathrm{~F} 24+0.672 * \mathrm{~F} 25+0.559 * \mathrm{~F} 26$

Factor 3 (X3): Salary and fringe benefits: include 6 observed variables, the impact of each items on factor 3 is shown as the following equation

$\mathrm{X} 3=0,801 * \mathrm{~F} 31+0.773 * \mathrm{~F} 32+0.632 * \mathrm{~F} 33+0.627 * \mathrm{~F} 34+0.615^{*} \mathrm{~F} 35+0.546^{*} \mathrm{~F} 37$

Factor 4 (X4): development opportunities: include 4 observed variables, the impact of each items on factor 4 is shown as the following equation 
$\mathrm{X} 4=0.823 * \mathrm{~F} 41+0.821 * \mathrm{~F} 42+0.811 * \mathrm{~F} 43+0.784 * \mathrm{~F} 44$

* Exploratory factor analysis (EFA) of job satisfaction (dependent variable)

Table 12. KMO and Bartlett's test

\begin{tabular}{|l|l|}
\hline Kaiser-Meyer-Olkin Measure of Sampling Adequacy. & 590 \\
Bartlett's Test of Sphericity Approx. Chi-Square & 45,058 \\
Df & 1 \\
Sig. & 000 \\
\hline
\end{tabular}

Table 13.Total Variance Explained

\begin{tabular}{|c|c|c|c|c|c|c|}
\hline \multirow{2}{*}{ Component } & \multicolumn{3}{|c|}{ Initial Eigenvalues } & \multicolumn{3}{c|}{ Extraction Sums of Squared Loadings } \\
\cline { 2 - 7 } & Total & \% of Variance & Cumulative\% & Total & \% of Variance & Cumulative $\%$ \\
\hline 1 & 1,574 & 78,724 & 78,724 & 1,574 & 78,724 & 78,724 \\
2 &, 426 & 21,276 & 100,000 & & & \\
\hline
\end{tabular}

Extraction Method: Principal Component Analysis.

Table 14. Rotated component matrix

\begin{tabular}{|l|l|}
\hline & Component \\
\cline { 2 - 2 } & 1 \\
\hline Commitment of lecturers to their universities & 887 \\
Proud of lecturers towards their universities &, 887 \\
\hline
\end{tabular}

\section{Extraction Method: Principal Component Analysis.}

\section{a. 1 components extracted.}

The table shows that $\mathrm{KMO}=0.59$ and sig $=0.000$ which is lower than 0.001 . This indicates appropriateness of dependent variables in the model. Furthermore, the rotated component matrix shows items loading on the same factor and all items have loading factors greater than 0.5 . Besides, Eigenvalue $=1.574>1$, and extracted variance $=78.724 \%>50 \%$, which are satisfactory.

\section{Regression analysis}

The correlation analysis is conducted between 4 factors and and job satisfaction. The purpose of correlation analysis is to quantify the linear relationship between the dependent variable and the independent variables as well as between independent variables before conducting regression analysis. In particular, the dependent variable is job satisfaction measured by 2 items which are commitment and pride of lecturers towards the universities where they are working. The results are shown as follows: 
Table 15. Correlations

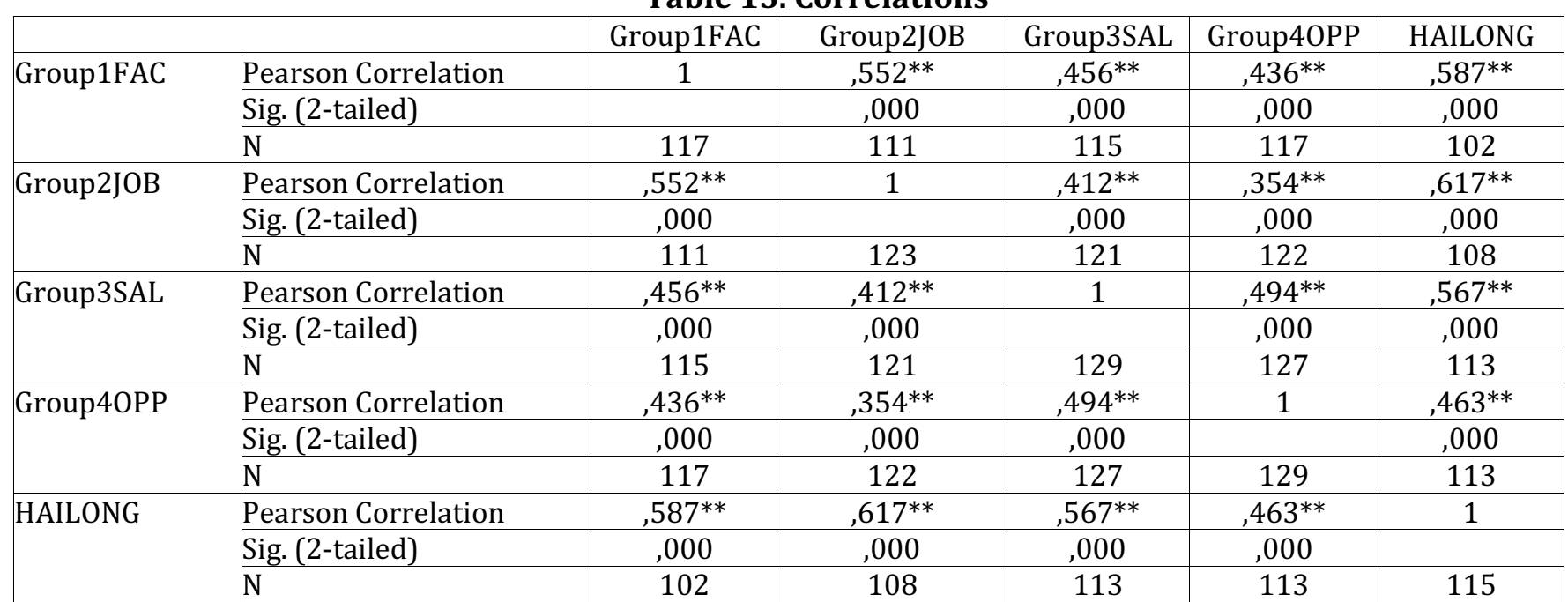

**. Correlation is significant at the 0.01 level (2-tailed).

The results in the above table show that the all 4 factors Facilities, Job Characteristics, Salary And Fringe Benefits, Development Opportunities have sig. $<0.05$. Therefore, it can be concluded that all factors are correlated with job satisfaction of lecturers. However, the Pearson's correlation coefficient between variables are relatively low $(<0.9)$ which reflects weak correlation between independent variable and dependent variables. Low correlation between independent variables means multicollinearity does not occur. Among the above variables, job characteristics (JC) has the strongest correlation coefficient (0.617), followed by facilities (FA) (0.587), salary and fringe benefits (0.567), and development opportunities has the lowest correlation coefficient (0.463). The results of correlation coefficients matrix are relatively consistent with the results of exploratory factor analysis table mentioned in the research method. The results of the correlation analysis between independent and dependent variables show that multivariate regression analysis is appropriate to quantify the impact of each factor on job satisfaction.

\section{Multiple regression analysis}

The multiple regression analysis is conducted between independent variables Facilities, Job Characteristics, Salary and Fringe Benefits, Development Opportunities with the dependent variable Job Satisfaction to investigate the impact of factors on lecturer job satisfaction. The results are shown as follows:

Table 16. Summary model

\begin{tabular}{|c|c|c|c|c|c|}
\hline Model & $\mathrm{R}$ & $\mathrm{R}$ Square & Adjusted R Square & $\begin{array}{c}\text { Std. Error of the } \\
\text { Estimate }\end{array}$ & $\begin{array}{c}\text { Durbin- } \\
\text { Watson }\end{array}$ \\
\hline 1 &, $628 \mathrm{a}$ &, 395 &, 388 &, 61155 &, 56955 \\
\hline 2 &, $693 \mathrm{~b}$ &, 481 &, 470 &, 55179 & 1,624 \\
\hline 3 &, $720 \mathrm{c}$ &, 518 &, 502 & \\
\hline
\end{tabular}

Table 16 shows that the value of R2 in model 3 is highest $(0,518)$ so model 3 is selected. Adjusted R Square of model 3 in the table shows that independent variables can explain 50.2\% variation of dependent variable Job Satisfaction. In other words, there are other factors affecting job satisfaction of lecturers apart from four factors Facilities, Job Characteristics, Salary and Fringe Benefits, Development Opportunities. 
Multiple linear regression analysis with Stepwise selection method, each independent variable is put into the model and inappropriate variables are removed. In this study, Development Opportunities is removed from the model due to inappropriateness. The results are shown as follows:

Table 17. ANOVAa

\begin{tabular}{|c|c|c|c|c|c|}
\hline Model & Sum of Squares & df & Mean Square & $\mathrm{F}$ & Sig. \\
\hline Regression & 22,708 & 1 & 22,708 & 60,717 &, $000 \mathrm{~b}$ \\
\hline Residual & 34,782 & 93 & ,374 & & \\
\hline Total & 57,489 & 94 & & & \\
\hline Regression & 27,645 & 2 & 13,823 & 42,611 & ,000c \\
\hline Residual & 29,844 & 92 & ,324 & & \\
\hline Total & 57,489 & 94 & & & \\
\hline Regression & 29,783 & 3 & 9,928 & 32,606 & ,000d \\
\hline Residual & 27,707 & 91 & ,304 & & \\
\hline Total - Tổng & 57,489 & 94 & & & \\
\hline \multicolumn{6}{|c|}{ a. Dependent Variable: HAILONG } \\
\hline \multicolumn{6}{|c|}{ b. Predictors: (Constant), Group2JOB } \\
\hline \multirow{2}{*}{\multicolumn{6}{|c|}{ c. Predictors: (Constant), Group2JOB, Group3SAL }} \\
\hline \multicolumn{5}{|c|}{ d. Predictors: (Constant), Group2JOB, Group3SAL, Group1FAC } & \\
\hline
\end{tabular}

In model 3, Sig $=0.000<0.05$ which indicates that the model is appropriate. In other words, there is significant difference among impact of facilities, job characteristics on job satisfaction.

In addition, each factor in the model is analyzed and tested to examined their impact on lecturer job satisfaction.

Table 18. Coefficientsa

\begin{tabular}{|c|c|c|c|c|c|c|c|}
\hline \multirow[t]{2}{*}{ Model } & \multicolumn{2}{|c|}{$\begin{array}{l}\text { Unstandardized } \\
\text { Coefficients }\end{array}$} & \multirow{2}{*}{\begin{tabular}{|c|}
$\begin{array}{c}\text { Standardized } \\
\text { Coefficients }\end{array}$ \\
Beta \\
\end{tabular}} & \multirow[t]{2}{*}{$\mathrm{t}$} & \multirow[t]{2}{*}{ Sig. } & \multicolumn{2}{|c|}{$\begin{array}{l}\text { Collinearity } \\
\text { Statistics }\end{array}$} \\
\hline & $\mathrm{B}$ & Std. Error & & & & & $\mathrm{B}$ \\
\hline 1 (Constant) & ,751 & ,294 & & 2,555 & 012 & & \\
\hline Group2JOB & ,755 & ,097 & ,628 & 7,792 &, 000 & 1,000 & 1,000 \\
\hline 2 (Constant) &, 543 & ,279 & & 1,945 & 055 & & \\
\hline Group2JOB & ,566 & 102 & ,471 & 5,526 &, 000 & ,776 & 1,288 \\
\hline Group3SAL & ,333 &, 085 & ,333 & 3,901 &, 000 & ,776 & 1,288 \\
\hline 3 (Constant) - Hằng số & ,329 & 282 & & 1,167 & 014 & & \\
\hline Group2JOB & , 459 & , 107 & ,382 & 4,281 &, 000 & ,666 & 1,503 \\
\hline Group3SAL & 241 & 090 & ,241 & 2,685 & 009 & ,660 & 1,516 \\
\hline Group1FAC & ,296 & ,112 & ,248 & 2,649 &, 010 & ,606 & 1,651 \\
\hline
\end{tabular}

a. Dependent Variable: HAILONG

From the above table, sig values of variables in model 3 are smaller than $5 \%$. Therefore, the relationship between Job Satisfaction and independent variables is presented in the following regression equation:

$$
\text { HAILONG }=0.382^{*} \mathrm{JOB}+0.241 * \mathrm{SAL}+0.248 * \mathrm{FAC}
$$

The regression equation shows that all three factors have a positive impact on Job Satisfaction. Thus, Job Characteristics has the highest impact on Job Satisfaction (0.382), followed by Facilities (0.248), and Salary and Fringe Benefits (0.241). The Development Opportunity factor is removed from the regression model because it is not suitable with the lowest correlation coefficient. 


\section{Hypothesis testing}

Testing for autocorrelation: It is shown from the table 3.10 that Durbin - Waston $=1.624$ which indicates that there is no autocorrelation.

Testing for multicollinearity: VIF coefficient in table 3.12 shows that there is no multicollinearity

Testing errors based on normal distribution, the results are shown as follows:

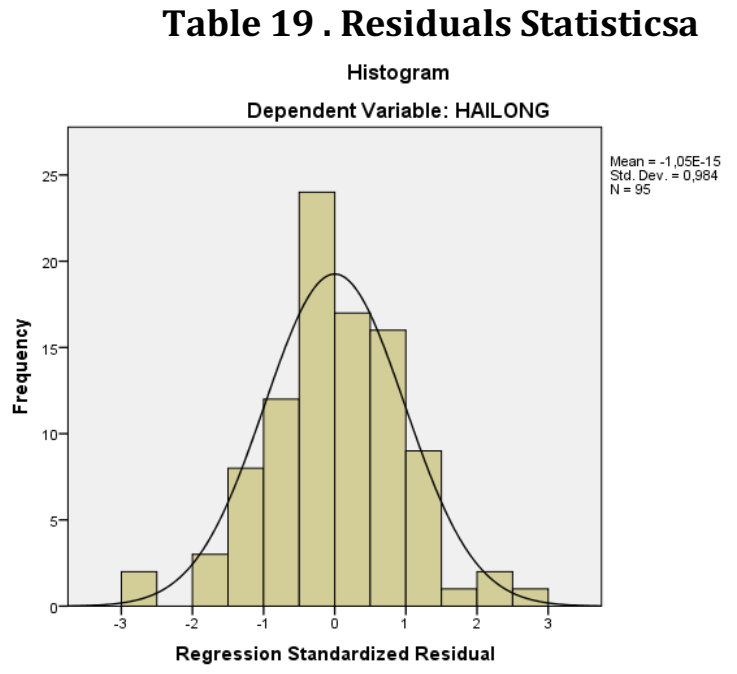

Graph 1: Standardized residual histogram

The results show that Std.Dev $=0.984$, so hypothesis Ho is accepted, it means the errors have a normal distribution

\section{Testing for heteroskedasticity}

Figure 2 below shows the relationship between standardized residuals and predicted values, we find that the residuals are relatively evenly distributed around their mean value of the zero. Therefore, there is no heteroskedasticity in this model.

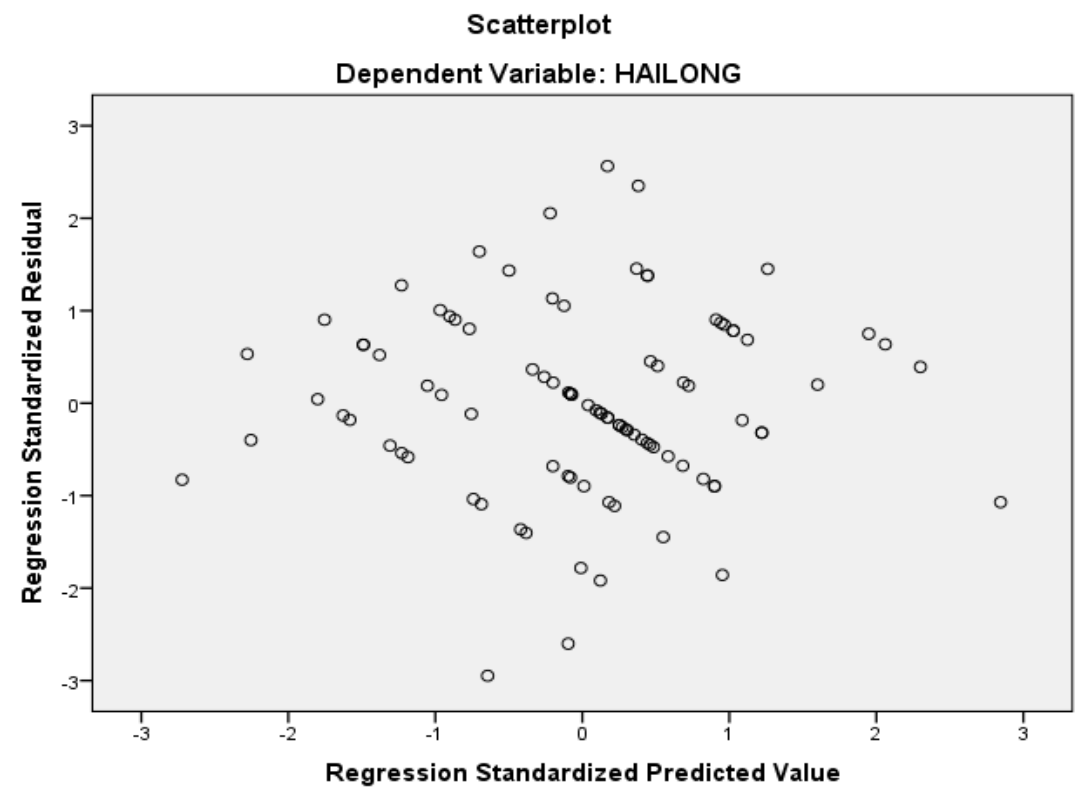

Graph 2: The scatter plot 
Thus, in the linear regression model, there is no heteroskedasticity, no autocorrelation, no multicollinearity and errors are normally distributed. Therefore, all variables in the model are statistically significant with a significance level of $5 \%$.

The multiple regression equation shows that there are 3 factors affecting job satisfaction which are Facilities, Job Characteristics, Salary and Fringe Benefits. In which Job Characteristics have the highest impact on job satisfaction, followed by Facilities, while Salary and Infring Benefits have the lowest impact on lecturer job satisfaction

\section{DISCUSSION}

\section{Job characteristics of lecturers (JOB)}

The research results show that the Job Characteristics are positively associated with job satisfaction of lecturers, this result confirm the hypothesis $\mathrm{H} 2$ and consistent with the results of Smith (2007). This factor has the strongest impact on satisfaction level with coefficient 0.459. The descriptive statistics in Table 3 show that level of job is moderate with mean values from 2.76 to 3. 19, and mean value of this factor is 2.61 . The fact is that most Vietnamese universities are applying a new system called credit-based training, therefore, the Ministry of Education and Training has issued specific regulations and guidelines so that universities can operate actively and effectively. Depending on the training objectives, each university may adjust accordingly. Furthermore, academic credit system is a flexible training method, facilitating learners to be proactive in terms of time, study plan and selection of subjects and lecturers. The application of accademic credit system to training lead to major changes in all aspects of training including regulations related to training programs, curriculum, lectures, scientific research, and time to enter and exit the class, managing grades, registration and enrollment of subjects. During the period of 2013-2019, universites are adapting to operate under new training system, therefore, facing many problems. It explains low satisfaction of lecturers. However, it is belived that universities can gain more trust and commitment of lecturers by conducting following activities:

Reviewing and completing regulations and policies related to teaching and scientific research Truly considering scientific research as a standard of professional quality in assessment and classification of emulation of officials and lecturers.

Organizing training courses for staff, lecturers to improving scientific research knowledge and skills in the following directions: academic training and applied research

Encouraging faculties to organize scientific seminars to give lecturers opportunities to meet leading experts, express their scientific views, thereby raising the qualifications of lecturers.

\section{Facilities (FAC)}

The research results showed that Facilities has a positive effect on job satisfaction (coefficient $=0.269$ ). This result is consistent with the hypothesis $\mathrm{H} 1$ and conclusions of previous studies of Smith (2007), Spector (1997), Locke (1969). According to the descriptive statistiscs in Table 3 , this factor has an acceptable level of job satisfaction (mean value of 2.61). As Vietnamese public universities were established since the 1960s, the classrooms, equipment are outdated and damaged. In engineer and technical universities, laboratory equipment and practical equipment have been funded by the Soviet Union since the 1980s. Furthermore, $70 \%$ of classrooms have no air conditioner, $30 \%$ of classrooms do not have a projector, $60 \%$ of classrooms do not have speaker and audio systems. In Hanoi, the average land area / student of universities is $13 \mathrm{~m}^{2} /$ student, in Ho Chi Minh City is $10 \mathrm{~m}^{2} /$ student. In both cities, approximately $30-40 \%$ of universities have an average land area per student of less than $5 \mathrm{~m}^{2} /$ student. Some universities have cramped conditions, such as National University of Civil 
Engineering, Hanoi with $0.84 \mathrm{~m}^{2}$ /student, Hanoi Law University with $0.67 \mathrm{~m}^{2}$ / student, Foreign Trade University, Hanoi with $1.08 \mathrm{~m}^{2} /$ student and University of Econimics Ho Chi Minh City with only $0.54 \mathrm{~m}^{2} /$ student. Many public universities still have to hire facilities outside to study or work overtime due to the lack of lecture halls. Currently, only $19.50 \%$ of students live in university dormitories. Among 32 traditional libraries of 34 universities participating in the survey, only $38.9 \%$ of libraries apply the current library standards of Vietnam or international standards, $39.3 \%$ of universities have an e-library, however, it does not meet the needs of students. In order to improve current facilities, universities can consider following ways:

Enhancing international cooperation, promoting association of training, thereby investing in facilities for teaching;

Increasing non-government budget investment is the solution to overcome the current shortage of facilities in universities. This source of investment mainly relies on nongovernmental organizations and ODA loan projects, taking advantages of the non-refundable funds of non-governmental organizations and enterprises.

Saving when builing universities in urban areas: building unviersites in urban areas by cooperating universities with independent training locations but sharing the other facilities such as libraries, laboratories, workshops, conference and convention centers, sport centers, domitories, and services.

\section{Salary and Fringe Benefits (SAL)}

The research results showed that Salary and Fringe Benefits has a positive impact on job satisfaction (coefficient $=0.241$ ). This result is consistent with the hypothesis $\mathrm{H} 3$ and confirms the results of previous studies of Henry et al. (2013), Smith (2007). The descriptive statistics in Table 3 showed low mean values ranging from 2.21 to 2.51 , which indicates that lecturers are not satisfied with salary and fringe benefits of their universitie. In Vietnamese public universities, lecturers' salary is calculated according to the state salary structure so there is no difference in salaries of univerisities. However, the benefits vary considerably depending on many different factors such as financial capacity, income distribution policy of universities. The benefits of university lecturers include compulsory and voluntary benefits. Compulsory benefits are benefits required by law such as social insurance and health insurance contributions. Voluntary benefits are given to lecturers by universities depending on their financial ability and distribution policy such as extra salaries, overtime pay, scientific research grants, allowance for business trip, bonuses. The survey results showed that financially independent public universities pay salaries and benefits for lecturers two or three times higher than public universities. Besides, lecturers of private universites have higher salaries than that of public universities. Therefore, lecturers in financially independent public universities and private universities have higher satisfaction level than that of public universities. Univerisites can enhance lecturers' satisfaction by considering following policies of salary and fringe benefits:

It is necessary to consider increasing the salary according to the performance, not rigidly applied according to the state regulations of increasing salary every 3 years.

Developing internal spending regulations in an open direction, depending on universities' performance for each year, developing policies for pay rise, bonuses and adjust policies annually.

Considering granting awards, funds supporting scientific research, curriculum, articles, excellent individual project implementation which brings practical benefits to universities. 
Increasing welfare expenses for officials and employees in holidays such as Tet holiday and vacation

\section{Development opportunities (OPP)}

The factor of Development Opportunities was removed from the regression model because it was inappropriate with the lowest correlation coefficient (1.436). However, according to the descriptive statistics in Table 3, this is a factor has acceptable level of job satisfaction with a mean value of 2.94. It means that universities created opportunities for lecturers to develop, and improve qualifications. Many universities encourage lecturers to improve their qualifications by providing time and funds for lecturers to study a Master program or Ph.D program; regularly organizing classes teaching foreign languages and research methods for lecturers. In addition to the policy of salary and benefits, each university should provide specific regulations on reward, discipline, training, retraining, promotion, appointment, and creating a friendly and cooperating environment among members of the organization. In addition, the leaders should make timely comments and assessments to the lecturers with constructive feedbacks to encourage teachers in performing professional tasks, committing to the educational career. Some recommendations for enhancing lecturers' development are explained as follows:

Investing and developing human resources: Many universities focus on training new skills, enhancing knowledge and technology for lecturers, establishing a separate training fund for lecturers.

Emphasizing personal creativity: universitie leaders should always appreciate and promote creative ideas, suggestions of lectureres to improve work.

Listening and selecting: universities should evalutate performance based on practical standards.

\section{CONCLUSION}

Nowadays, universities are facing great challenges due to fierce competition in recruiting and retaining lecturers. This requires university management to improve personnel management, operating procedures to improve the quality of training. Job satisfaction will motivate lecturers to improve the effectiveness of teaching and scientific research activities. The study on factors affecting lecturer job satisfaction helps universities to develop appropriate policies to retain and develop employees, making them more satisfied, and attracting competent lecturers as well as preventing "brain drain". In this study, 3 out of 4 factors positively affect job satisfaction: Job Characteristics, Salary and Fringe Benefits, and Development Opportunities, in which, Job Characteristics has the strongest impact, while Salary and Fringe Benefits has the lowest impact.

\section{References}

Babar, Z. B., \& Kashif, U, R. (2010), A study examining the lectures and student's satisfaction in higher education, Foundation University and Iqra University Pakistan.

Best, E. E. (2006), Job satisfaction of teachers in Krishna primary and secondary schools, The University of North Carolina at Chapel Hill, United States - North Carolina.

Bhuian, S. N., \& Menguc, B. (2002), An Extension And Evoluation Of Job Characteristics, Organizational Commitment And Job Satisfaction In An Expatriate, Quest Worker, Sales Setting, Journal Of Personal Selling And Sales Management, 22(1): 1-11.

Cronin, J.J., \& Taylor, S. A (1992), Measuring service quality: A reexamination and extension, Journal of Marketing, Vol 56 (July): 55-6, https://doi.org/10.1177/002224299205600304 
De Witte. H. (2005), Job insecurity, extrinsic and intrinsic job satisfaction and affective organizational commitment of maintainance workers in a parastatal. S.A fr.J. Bus.Manage, 36(2):27-38.

Denlinger, S. L. (2002), Teaching as a profession: A look at the problem of teacher deficits, The Clearing House, 75(3), 116-116. https://doi.org/10.1080/00098650209599248

Griffeth, R. W., Hom, P.W., \& Gaertner, S. (2000), A Meta-analysis of Antecedents and Correlates of Employee Turnover, Update, Moderator Tests, and Research Implications for the Next Millennium, Journal Of Management, 26, 3: 463-488.

Herzberg, F. (1959), The motivation to work, New York.

Hieu Tran Minh. (2013), Teacher's job satisfaction in An Giang University, Journal Of Scientific, 1: 91-100.

Hoppock, R. (1935), Job satisfaction. Oxford, England: Harper.

Hughes, V. M. (2006), “Teacher Evaluation practice and Teacher Job Satisfactionin partial fulfillmen of the requirement for the degree Doctor of Education", University odd Misouri - Columbia.

Hunt, J. W., \& Saul, P . N. (1975). The relationship of age, tenure and job satisfaction in male and female, The academy of management journal, 18(4): 690-702.

Henry, J., Motena, T., \& Casius, D. (2013), Impact investigation of organisational commitment on intention to leave of public secondary school teachers in Tanzania, Developing Country Studies, 3(11):78-91. Teacher job satisfaction in Vietnam National University of Forestry 306

Lee, S. (2007), "Vroom's expectancy theory and the public library customer motivation model", Library Review, 56(9), 788-796.

Lester, P. E. (1987), “Development and Factor Analysis of the Teacher Job Satisfaction Questionnaire (TJSQ)”, Educational and Psychological Measurement, 47(1), 223-233. https://doi.org/10.1177/0013164487471031

Locke, E. A. (1969). What is job satisfaction?, Organizational Behavior and Human performance, 4: 309-336.

Lutfi, A., \& Hai, M. Y. (2009), “Determining Factor that affect Satisfaction students in Undergraduate Tourism Education"

Minh, D. Q. (2013). Personal factor and faculty job satisfaction in Vietnam National University-Hochiminh City, International research in Education, , 2(2):145-158.

Mussie, T. T. (2012), “Factors Affecting College lectures' Satisfaction with Major Curriculum: Evidence from Nine Years of Data", International Journal of Humanities and Social Science, 1/2012

Rounds, J. B., Dawis, R., \& Lofquist, L. H. (1987), “Measurement of person-environment fit and prediction of satisfaction in the theory of work adjustment", Journal of Vocational Behavior, 31(3), 297-318 https://doi.org/10.1016/0001-8791(87)90045-5

Sharma, R. D., \& Jyoti, J. (2009), “Job satisfaction of university teachers: an empirical study”, Journal of Services Research, 9(2), 51-80.

https://www.researchgate.net/profile/Jeevan_Jyoti/publication/286142423_Job_satisfaction_of_university_teach ers_An_empirical_study/links/583e5e6708aeda6968071146/Job-satisfaction-of-university-teachers-Anempirical-study.pdf

Smith, T. W. (2007). "Job satisfaction in the United States". http://citeseerx.ist.psu.edu/viewdoc/download;jsessionid=D9F3040CE954BA069A94F41B598BCE0F?doi=10.1.1 $.173 .2106 \&$ rep=rep1\&type $=$ pdf

Spector, P.E. (1997). Job satisfaction: Application, assessment, causes and consequences, Thousand Oaks,CA,Sage Publications, Inc. 